\title{
Evaluation of Pre-heating Effects on Marginal Adaptation of Resin-based Materials
}

\author{
IONUT TARABOANTA ${ }^{1}$, SIMONA STOLERIU ${ }^{1 *}$, GIANINA IOVAN ${ }^{1}$, ANTONIA MOLDOVANU ${ }^{1}$, ANDREI GEORGESCU ${ }^{1}$, \\ MAGDALENA RUSU NEGRAIA2 ${ }^{2}$, SORIN ANDRIAN ${ }^{1}$ \\ ${ }^{1}$ Grigore T. Popa University of Medicine and Pharmacy lai, Faculty of Dental Medicine, 16 Universitatii Str., 700115, Iasi, Romania \\ ${ }^{2}$ Dunarea de J os University, Faculty of Medicine and Pharmacy, 47 Domneasca Str., 800008, Galati, Romania
}

\begin{abstract}
The aim of the study was to compare the marginal adaptation of three different resin-based materials used for direct restoration: hybrid composite resin (Gaenial Posterio, GC Corporation), a compomer (Dyract eXtra, Dentsply Sirona), and a giomer (Beautifil II, Shofu Dental) applied at room temperature or after preheated at preheating 50 and $60^{\circ} \mathrm{C}$. Class II cavities were prepared on proximal surfaces of extracted teeth and randomly divided in 3 groups according to the material used for restoration. In each group five cavities were restored using the materials at room temperature (subgroup 1), five cavities were restored using preheated materials at 50ㄷ (subgroup 2), and five cavities were restored using preheated materials at $60^{\circ} \mathrm{C}$ (subgroup 3). The teeth were stored in distilled water for 14 days and then were immersed in $2 \%$ methylene blue buffered dye solution ( $\mathrm{pH}=7$ ) for 4 hours. The teeth were transversally cut and the sections were examined using optical microscope (Carl-Zeiss AXIO Imager Alm) at 50x magnification and the dye penetration was evaluated according to 4 scores. Decreased microleakage and fewer gap formation were recorded for all filling materials after they have been heated at 50 or $60^{\circ} \mathrm{C}$. Pre-warming of resin-based materials improves the adaptation of these materials to tooth structures.
\end{abstract}

Keywords: preheating, composite resin, compomer, giomer, microleakage, SEM

The major goal of restorative dentistry is to obtain an ideal restoration. From the practitioner $1 / 4 \mathrm{~s}$ point of view this objective must be achieved by using long lasting, highly aesthetic materials, and a less sensitive technique for placement in the cavities. Composite resins have become the most used material for direct restoration. Some of the issues claimed by the practitioners when using these materials include increasing the depth of cure, increasing the conversion rate and reducing the time of curing. In the last decades an increased interest was manifested by the producers to improve mechanical characteristics, handling properties and aesthetic aspect of these materials.

Due to their good mechanical properties, micro-hybrid and nano-hybrid composite resins are used to restore the cavities in occlusal stress area. There are some disadvantages when using these materials: doubtable adaptation to the cavity walls [1], voids formation in the bulk material [2] and difficulties when displacing the material from the syringe. In the complex environment of oral cavity, these materials are prone to degradation [3-7] and the tooth-material adhesion to breaking. Efforts were made in time in order to improve marginal adaptation of these composite resins, by controlling the polymerization shrinkage [8-10], by placing a flowable composite resin as an intermediate layer [11] or by reducing the viscosity of these highly filled composite using preheating [12-15]. For years the producers asked the practitioners to refrigerate the composite resins during storing or before use in order to maintain the quality of the materials. Now it is known that this is not a good approach. On a contrary, warming the composite resin to the body temperature or higher might improve mechanical properties and might reduce the curing time.

The aim of the study was to compare the marginal adaptation of three different resin-based materials used for direct restoration: a composite resin, a compomer and a giomer applied with or without preheating.

\section{Experimental part}

Extracted human molars having no cracks, caries lesions or restorations on the proximal surfaces were selected for this study. A single operator prepared on the mesial and distal surfaces of each tooth two standardized box-only class II cavities having a wide of $3 \mathrm{~mm}$ and a depth of $2 \mathrm{~mm}$. Half of the cavities $(n=45)$ were prepared by placing the gingival margin $2 \mathrm{~mm}$ below the cementoenamel junction (CEJ) and the other half $(n=45)$ were prepared by placing the gingival margin $1 \mathrm{~mm}$ upper than the CEJ. Buccal and lingual walls of the cavities were parallel to each other and the internal angles and gingivalaxial line angle were rounded by using a straight fissure carbide bur (FG no. 557, SS White Dental, USA). The cavities were restored using three resin-based materials: a giomer (Beautifil II, Shofu Dental) (group 1), a compomer (Dyract eXtra, Dentsply Sirona) (group 2) and a hybrid composite resin (Gaenial Posterior, GC Corporation) (group 3). Chemical composition of the materials used in the study are presented in table 1.

All three materials were used in conjunction with an universal bonding agent (G Premio Bond, GC Corporation) applied in self-etch strategy. For bonding procedure, bonding agent was applied using applicator brushes by scrubbing the tooth surface for $20 \mathrm{~s}$, gently air drying for $5 \mathrm{~s}$ and then light curing for $20 \mathrm{~s}$. A universal Tofflemire matrix retainer and a matrix band were placed around the tooth and pressed with the fingers in the cervical area in order to prevent overhanging of the material to the gingival margin. Two horizontal layers of restorative materials were used for the cavities having the gingival wall placed upper than CEJ and three horizontal layers were used for the cavities having the gingival wall placed lower than CEJ restoration. Each layer has been polymerized for 40 s using a LED light unit (LED B, Guilin Woodpecker Medical Instrument Co., Ltd, China) having the light intensity of $850-1000 \mathrm{~mW} / \mathrm{cm}^{2}$ and the wavelength of $420-480 \mathrm{~nm}$. In each group, the

\footnotetext{
* email: stoleriu_simona@yahoo.com
} 
Table 1

CHEMICAL COMPOSITION OF RESIN-BASED MATERIALS FOR RESTORATION

\begin{tabular}{|c|c|c|c|c|}
\hline $\begin{array}{c}\text { Material for } \\
\text { restoration }\end{array}$ & Filler & $\begin{array}{c}\text { Particle } \\
\text { size range }\end{array}$ & $\begin{array}{l}\text { Mean particle } \\
\text { size }\end{array}$ & Base resin \\
\hline Beautifil II & $\begin{array}{l}\text { Multi-functional glass filler and S-PRG } \\
\text { filler based on fluoroboroaluminosilicate } \\
\text { glass }\end{array}$ & $\begin{array}{l}0.01 \text { to } 4.0 \\
\mu \mathrm{m}\end{array}$ & $0.8 \mu \mathrm{m}$ & $\begin{array}{l}\text { Bis-GMA, } \\
\text { TEGDMA }\end{array}$ \\
\hline Dyract eXtra & Strontium fluoride glass & $\begin{array}{l}0,1 \text { to } 1.4 \\
\mu \mathrm{m}\end{array}$ & $0.8 \mu \mathrm{m}$ & $\begin{array}{l}\text { Bis- } \\
\text { GMA,TEGDMA } \\
\text { TMPTMA }\end{array}$ \\
\hline $\begin{array}{l}\text { Gaenial } \\
\text { Posterior }\end{array}$ & $\begin{array}{l}\text { Pre-polymerized fillers: } \\
\text { strontium and lanthanoid flum, } \\
\text { fluoroaluminosilicate }\end{array}$ & $16-17 \mu$ & unspecified & $\begin{array}{l}\text { UDMA , } \\
\text { dimethacrylate } \\
\text { co-monomers }\end{array}$ \\
\hline
\end{tabular}

material used for restoration was applied at room temperature $(n=15)$ (subgroup 1), after pre-heating fir 3 min at $50^{\circ} \mathrm{C}(\mathrm{n}=15)$ (subgroup 2) and after pre-heating for 3 min at $60^{\circ} \mathrm{C}(\mathrm{n}=15)$ (subgroup 3) in a dry-bath incubator (Labline Equipment PVD LTD). After making the restorations the matrix was removed and the restored teeth were placed in distilled water for 1 week.

After that the external surfaces of the teeth were coated with two layers of water resistant nail varnish, except the surface of the restoration and an area of $1 \mathrm{~mm}$ around the restoration, then the teeth were immersed in $2 \%$ methylene blue dye solution ( $\mathrm{pH}=7$ ) for $4 \mathrm{~h}$. The teeth were sectioned in mesial-distal direction using diamond discs (Komet Dental, Brasseler GmbH\&Co, Germany) atlow speed under cooling with water.

The sections were examined using an optical microscope (Carl-Zeiss AXIO Imager AIm) coupled with a high resolution digital camera at $50 x$ magnification. The dye penetration was assessed according to the following scores: 0 no dye penetration; 1 dye penetration on less than a half of the interface; 2 dye penetration on more than a half of the interface, but less then the whole interface; 3 complete dye penetration of the interface, without involving the axial wall; 4 complete dye penetration of the interface, involving the axial wall. The sections were examined by two different evaluators, blinded to the materials and the method. For each image the two examiners confronted the score and the final score resulted as a common decision.

Our study was done in accordance with the Ethical Committee regulations and in accordance to some published models [16-20].

\section{Results and discussions}

Examples of some optical images of the samples in groups 1-3 and in subgroups 1-3 when the cervical margin of the cavity was placed upper than CEJ are presented in figure 1. In group 1 the scores of marginal leakage varied in subgroup 1 from 2 to 3 , in subgroup 2 and in subgroup 3 from 1 to 4 . One sample scored with 4 was recorded in subgroup 2 and one sample in subgroup 3 . In group 2 the scores of marginal leakage varied in subgroups 1-3 from 1 to 3 . No score of 4 was found in all the subgroups in group 2. In group 3 the scores of marginal leakage varied in subgroup 1 from 1 to 2 and in subgroup 3 from 0 to 2 . In subgroup 2 only scores of 1 and 2 were recorded.

Optical images of material-tooth interface at the gingival wall when the cervical margin of the cavity was placed lower than CEJ are presented in figure 2 . In group 1 the scores of marginal leakage varied in subgroup 1 and in subgroup 2 from 1 to 3 . In subgroup 3 only score of 2 was recorded for all samples. In group 2 the scores of marginal leakage varied in subgroups 1 and 3 from 1 to 3 and in subgroup 2 only scores of 2 and 3 were recorded. In group

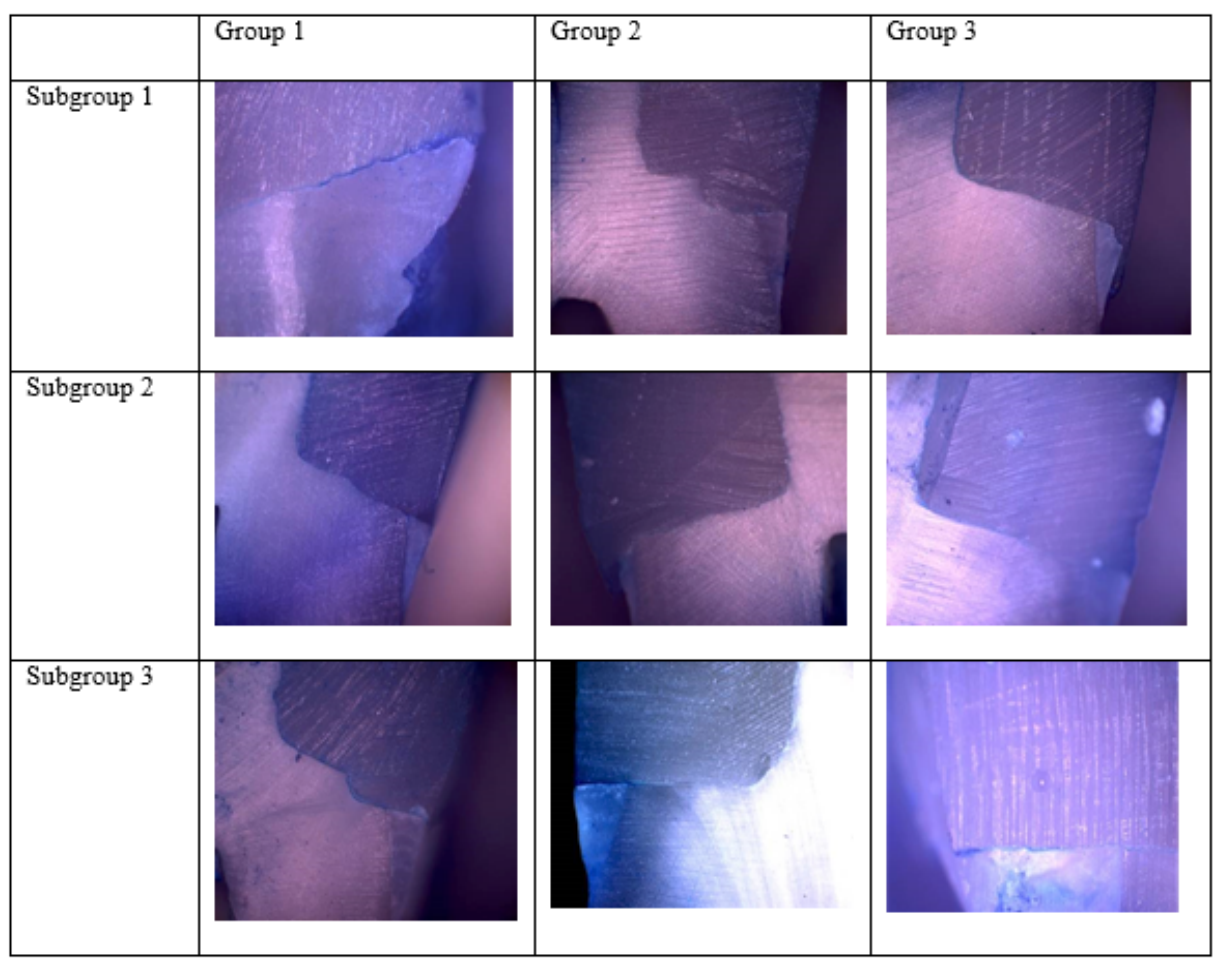

MATERIALE PLASTICE $\bullet 55$ No. 2 \2018
Fig. 1. Optical images of material-tooth interface at gingival margin placed upper than CEJ in groups 1-3 and subgroups $1-3$ 

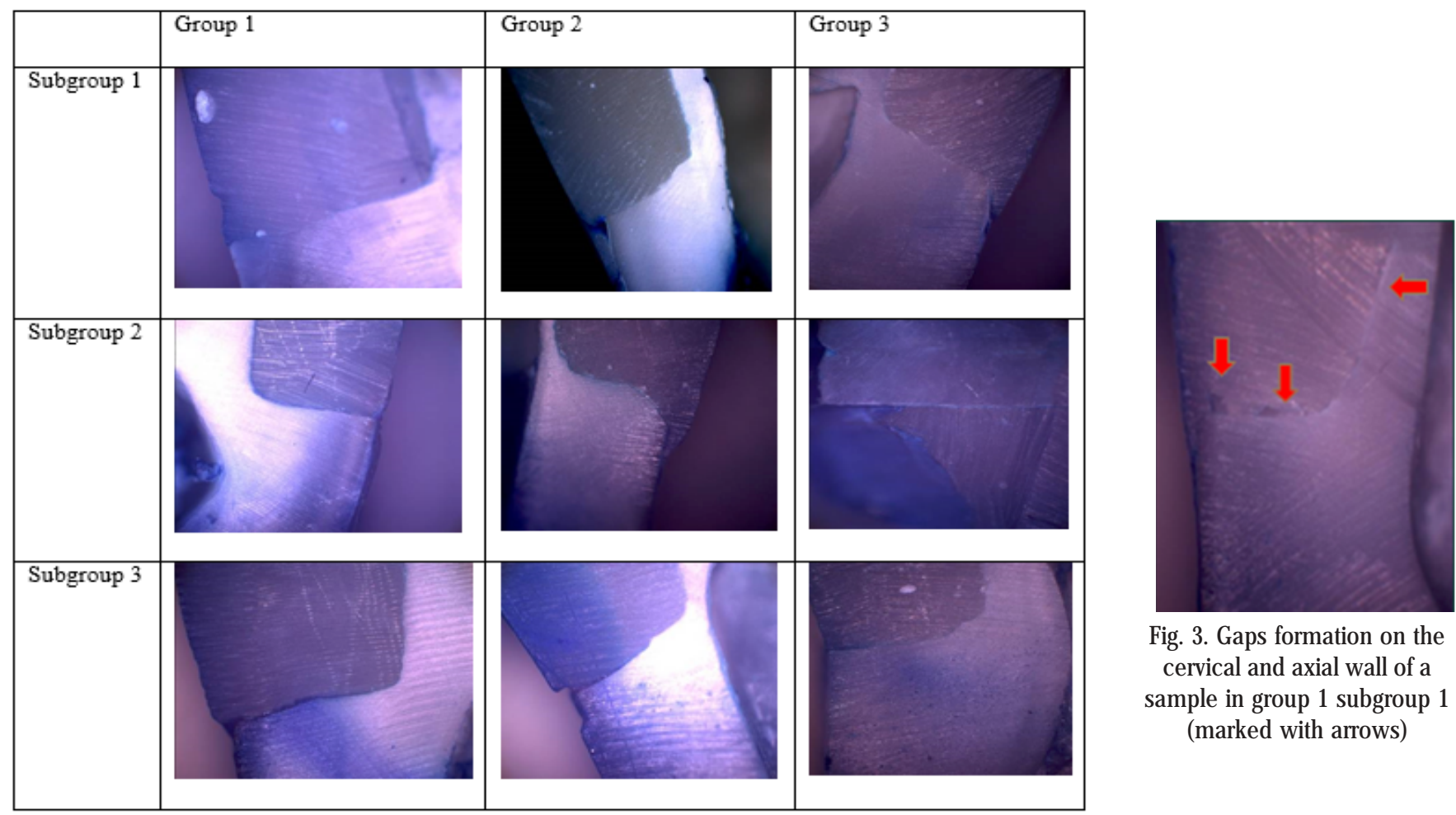

Fig. 3. Gaps formation on the cervical and axial wall of a sample in group 1 subgroup 1 (marked with arrows)

Fig. 2. Optical images of material-tooth interface at gingival margin placed lower than CEJ in groups 1-3 and subgroups 1-3

3 the scores of marginal leakage varied in subgroup 2 from 1 to 2 and in subgroup 3 from 0 to 2 . In subgroup 1 all the samples were scored with 2 . No score of 4 was found in all groups and subgroups.

Few gap formation was observed in some samples in group 1 subgroup 1 and subgroup 2 and in group 2 subgroup 1 and subgroup 2. Mostly they were located at the cervical tooth-material interface. Only one sample presented also gaps on the axial wall of the cavity (fig. 3).

The mean values of marginal leakage and standard deviation when the gingival margin was placed upper than CEJ and lower than CEJ were presented in tables 2 and 3, respectively. When gingival margin was placed lower than CE], decreased mean values of scores were recorded in groups 2 and 3 when compared to group 1 and in subgroups 2 and 3 when compared to subgroup 1 . The lowest mean value of scores was registered in group 3 subgroup 3 and the highest in group 1 subgroup 1 . Similar or almostsimilar

\begin{tabular}{|l|l|l|l|}
\hline & Group 1 & Group 2 & Group 3 \\
\hline Subgroup 1 & $2.6 \pm 0.5(\mathrm{a}, \mathrm{A})$ & $2.4 \pm 0.6(\mathrm{~b}, \mathrm{~B})$ & $2.2 \pm 0.8(\mathrm{c}, \mathrm{C})$ \\
\hline Subgroup 2 & $2.4 \pm 0.5(\mathrm{a}, \mathrm{A})$ & $2.2 \pm 0.2(\mathrm{~b}, \mathrm{~B})$ & $2.0 \pm 0.4(\mathrm{c}, \mathrm{C})$ \\
\hline Subgroup 3 & $2.2 \pm 0.2(\mathrm{a}, \mathrm{A})$ & $2.0 \pm 0.5(\mathrm{~b}, \mathrm{~B})$ & $1.8 \pm 0.4(\mathrm{c}, \mathrm{C})$ \\
\hline $\begin{array}{l}\text { The same lowercase letters on the columns and uppercase on } \\
\text { the rows represent no statistically significant results (Mann } \\
\text { Whitney statistical test) }\end{array}$ \\
\hline
\end{tabular}

\begin{tabular}{|l|l|l|l|}
\hline & Group 1 & Group 2 & Group 3 \\
\hline Subgroup 1 & $2.4 \pm 0.3(\mathrm{a}, \mathrm{A})$ & $2.2 \pm 0.8(\mathrm{~b}, \mathrm{~B})$ & $2.0 \pm 0.0(\mathrm{c}, \mathrm{C})$ \\
\hline Subgroup 2 & $2.2 \pm 0.8(\mathrm{a}, \mathrm{A})$ & $2.0 \pm 0.4(\mathrm{~b}, \mathrm{~B})$ & $1.8 \pm 0.4(\mathrm{c}, \mathrm{C})$ \\
\hline Subgroup 3 & $2.0 \pm 0.5(\mathrm{a}, \mathrm{A})$ & $1.8 \pm 0.3(\mathrm{~b}, \mathrm{~B})$ & $1.6 \pm 0.5(\mathrm{c}, \mathrm{C})$ \\
\hline $\begin{array}{l}\text { The same lowercase letters on the columns and uppercase on the } \\
\text { rows represent no statistically significant results (Mann Whitney } \\
\text { statistical test) }\end{array}$
\end{tabular}

results where recorded in group 2 subgroup 1 and in group 1 subgroup 2, in group 3 subgroup 1, group 2 subgroup 2 and group 1 subgroup 3 , in group 3 subgroup 2 and group 2 subgroup 3.

When gingival margin was placed lower than CEJ, decreased mean values of scores were recorded in groups 2 and 3 when compared to group 1 and in subgroups 2 and 3 when compared to subgroup 1 . The lowest mean value of scores was registered in group 3 subgroup 3 and the highest in group 1 subgroup 1. Similar or almost similar results where recorded in group 2 subgroup 1 and in group 1 subgroup 2, in group 3 subgroup 1, group 2 subgroup 2 and group 1 subgroup 3 , in group 3 subgroup 2 and group 2 subgroup 3.

The results were statistically analyzed using nonparametric Mann Whitney test. No significant differences $(p>0.01)$ were obtained when compared the results between subgroups in the same group (marked with the same lowercase letter in the subgroups of the same group

\section{Table 2}

THE MEAN VALUES OF MARGINAL LEAKAGE \pm STANDARD DEVIATION AT THE GINGIVAL MARGIN PLACED UPPER THAN CEJ
Table 3

THE MEAN VALUES OF MARGINAL LEAKAGE \pm STANDARD DEVIATION AT THE GINGIVAL MARGIN PLACED LOWER THAN CEJ 
in tables 2 and 3). Also, no statistical significant differences $(p>0.01)$ were obtained when compared the results between groups (marked with the same uppercase letter in the same subgroup of different groups in tables 2 and 3 ).

Some previous studies have concluded that composite preheating might worsen the marginal adaptation due to the increased monomer conversion and polymerization rates [21, 22] and increased polymerization shrinkage [23, 24]. Due to polymerization shrinkage and to completely different thermal expansion of composite resins when compared to tooth structures [25], high interfacial stress might result, which will have negative effects on marginal integrity and marginal adaptation [26]. These findings were not confirmed by the results of our study and of other studies [27], including similar applications in other fields of medicine $[28,29]$. Also, conventional composites provided a better adaptation to the cavity walls after preheating when compared to those maintained at room temperature due to lower film thickness when heated at 54 or $60^{\circ} \mathrm{C}$ [30]. Irrespective of the material used for restoration in our study, decreased values of microleakage were recorded when the materials were preheated at $50^{\circ} \mathrm{C}$ and $60^{\circ} \mathrm{C}$. This could be explained by the reduction of materials viscosity by prewarming [15]. Increased flowable characteristics will improve the adaptation of the material to the cavity walls and will provide a better seal [31]. It was claimed that the flowable characteristics of preheated highly filled composite are similar to those of flowable composite [32-34]. When heated, many polymers exhibit lower viscosity due to thermal vibrations that force the composite monomer or oligomers further apart and allow them to slide by each other more readily [35]. At increased temperature, decreased viscosity and increased polymer chains mobility appear, which have as result an additional polymerization reaction and higher cross-linking (higher conversion) [21]. Unfortunately, a high rate of conversion is generally associated with increased polymerization shrinkage. The increase of polymerization temperature can increase the conversion of dimethacrylate monomers, but only up to a certain temperature limit [21]. Over this limit the conversion decrease with the increase of temperature. A possible explanation is the evaporation of the reactant and the degradation of the photoinitiator [21]. Some studies concluded that the flow characteristics of the composite resins are in correlation with the type and ratio of the resin matrix [36], the content, size, shape and pretreatment (silanization) of the fillers [37].

The reduction of gap formation at material-tooth interface has also been demonstrated in previous studies [38]. In our study gaps were observed especially at toothmaterial cervical interface. Due to the fact that the intensity of the light used for photopolymerization is higher at the surface and decreases as it goes deeper in the composite mass, the lower layer of the material will reach the gel point slowly than upper layer [39]. As a result, poor adaptation at the gingival wall in terms of gap formation might appear due to stress relief by flow [40].

One limitation of this study is represented by the low number of the samples. Heterogeneous results obtained for the samples included in the groups is another concern. There was no standardized time to insert the materials in the cavity. In previous studies it was demonstrated that warmed resin loses approximately $50 \%$ of the temperature within 2 minutes after removal from the heating source and about $90 \%$ within 5 minutes [41]. Due to the fact that composite cools rapidly after removal from the heating unit, it is mandatory to save any time to enhance the performance of preheated composite. The degree of cooling of preheated materials depends on the practitioner $1 / 4 \mathrm{~s}$ abilities, the distance between the heating device and the cavity and the clinical accessibility to the cavity. In our study all the materials have been maintained at a constant temperature, a situation which not simulate a clinical situation. Assessing the influence of preheating in non-isothermal conditions should be a better approach.

\section{Conclusions}

Pre-heating at 50 and $60^{\circ} \mathrm{C}$ of composite resin, compomer and giomer leaded to a lower microleakage and a better cervical margin adaptation, but the results were notstatistically significant. Composite resin presented the best marginal adaptation after heating at enamel and dentine margins, followed by compomer and giomer.

\section{References}

1.KORKMAZ, Y, OZEL, E., ATTAR, N., J. Adhes. Dent., 9, 2007, p. 189. 2.OPDAM, N.J.M., ROETERS, J.J.M., JOOSTEN, M., VEEKE, O., Dent. Mater., 18, 2002, p. 58.

3.MUNTEANU, B., ANDRIAN, S., IOVAN, G., GHIORGHE, A., NICA, I., STOLERIU, S., Mat. Plast., 52, no. 3, 2014, p. 279.

4.NICA, I., IOVAN, G., GHIORGHE, A., STOLERIU, S., PANCU, G., ANDRIAN, S., Mat. Plast., 52, no. 3, 2014, p. 282.

5.RADU, M.T., TAMPU, D., GHIORGHE, A., STOLERIU, S., ANDRIAN, S., Int. J. Med. Dent, 14, 4, 2010, p. 269.

6.BALAN, A., ANDRIAN, S., SAVIN, C., SANDU, A. V., PETCU, A., STOLERIU, S., Rev Chim (Bucharest), 66, no. 4, 2015, p. 562.

7.MIHALAS, E., MAXIM, A., BALAN, A., MATRICALA, L., MAXIM, D. C., TOMA, V., PETCU, A., Rev.Chim. (Bucharest), 66, no. 6, 2015, p. 843. 8.IOVAN G., STOLERIU, S., MOLDOVANU, A., MOROGAI, S., ANDRIAN, S., Int. J. Med. Dent , 15, 3, 2011, p. 254.

9.GEORGESCU, A., IOVAN, G., STOLERIU, S., TOPOLICEANU, C., ANDRIAN S., Int. J. Med. Dent , 14, 2, 2010, p. 141.

10.ANDRIAN, S., IOVAN, G., STOLERIU, S., GEORGESCU, A., APOSTOLIDE, D., Int. J. Med. Dent, 13, 1, 2009, p. 38.

11.LINDBERG, A., VAN DIJKEN, J.W.V., HORSTEDT, P., Clin. Oral Investig., 9, 2005, p. 77.

12.LUCEY, S., LYNCH, C.D., RAY, N.J ., BURKE, F.M., HANNIGAN, A., J. Oral Rehabil., 37, 2010, p. 278.

13.WAGNER, W.C., AKSU, M.N., NEME, A.L., LINGER, J.B., PINK, F.E., WALKER, S., Oper. Dent., 33, 2008, p. 72.

14.DARONCH, M., RUEGGEBERG, F.A., MOSS, L., FERNANDO DE GOES, M., J. Esthet. Restor. Dent., 18, 2006, p. 340.

15.BLALOCK, J.S., HOLMES, R.G., RUEGGEBERG, F.A., J. Prosthet. Dent., 96, 2006, p. 424.

16.AGHEORGHIESEI CORODEANU, D.T., POROCH, V., 6th LUMEN International Conference on Rethinking Social Action Core Values, 16-19 April 2015, Iasi, Romania, Rethinking Social Action. Core Values, p. 33.

17.TOADER, E., TOADER, T., Revista Romana de Bioetica, 10, no. 3, 2012, p. 66.

18.TOADER, E., Revista Romana de Bioetica, 8, no. 2, 2010, p. 157. 19.DOBRIN, R., CIOBICA, A., TOADER, E., POROCH, V., Rev. Chim. (Bucharest), 67, no. 9, 2016, p. 1778.

20.BALAN, G.G., TRIFAN, A., SAVIN, C., BALAN, A., GOLOGAN, E.. Revista de Cercetare si Interventie Sociala, 55, 2016, p. 244.

21.DARONCH, M., RUEGGEBERG, F.A., DE GOES, M.F., J. Dent. Res., 84, 2005, p. 663.

22.TRUJ ILLO, M., NEWMAN, S.M., STANSBURY, J.W., Dent. Mater., 20, 2004, p. 766.

23.SILIKAS, N., ELIADES, G., WATTS, D.C., Dent. Mater., 16, 2000, p. 292.

24.LOHBAUER, U., ZINELIS, S., RAHIOTIS, C., PETSCHELT, A., ELIADES, G., Dent. Mater., 25, 2009, p. 514.

25.SIDHU, S.K., CARRICK, T.E., MCCABE, J.F., Dent. Mater.,20, 2004, p. 435.

26.WATTS, D.C., ISSA, M., IBRAHIM, A., WAKIAGA, K., AL-SAMADINI, M., SILIKAS, N., Dent. Mater., 24, 2008, p. 129. 
27.SOLIMAN, E.M, ELGAYAR, I.L., KAMAR, A. A., Alex. Dent. J., 41, 2016, p. 4.

28.BALAN, G.G., PAVEL, L., SANDU, A.V., STEFANESCU, G., TRIFAN, A.V., Mat. Plast., 53, no.4, 2016, p. 791.

29.BALAN, G.G., ROSCA, I., URSU, E.L., DOROFTEI, F., BOSTANARU, A.C., HNATIUC, E., NASTASA, V., SANDRU, V., STEFANESCU, G., TRIFAN, A., MARES, M., Infection and Drug Resistance, 11, 2018, p.727. 30.DIONYSOPOULOS, D., TOLIDIS, K.,GERASIMOU., P., KOLINIOTOUKOUMPIA, J. Dent.Sci., 9, 4, 2014, P. 313.

31.KNIGHT, J.S., FRAUGHN, R., NORRINGTON, D., Gen. Dent., 54, 2006, p. 14.

32.PAPADOGIANNIS, D.Y., LAKES, R.S., PAPADOGIANNIS, Y., PALAGHIAS, G., HELVATJOGLU-ANTONIADES, M., Dent. Mater., 24, 2008, p. 257. 33.MOSZNER, N., KLAPDOHR, S., Int. J. Nanotechnol., 1, 2004, p. 130. 34.RUEGGEBERG, F.A., DARONCH, M., BROWNING, W.D., DE GOES, M.F., J. Esthet. Restor. Dent., 22, 2010, p. 314.
35.WAGNER, W.C., ASKU, M.N., NEME, A.L., LINGER, J.B., PINK, F.E., WALKER, S., Oper. Dent., 33, 2008, p. 7.

36.TAYLOR, D.F., KALACHANDRA, S.K., SANKARAPANDIAN, M.,.MCGRATH J.E., Biomat., 19, 1998, p. 197.

37.SCHULZE, K.A., ZAMAN, A.A., SODERHOLM, K.J ., J. Dent., 31, 2003, p. 373.

38.CHOUDHARY, N., KAMAT, S., MANGALA, T.M., THOMAS, M., J. Conserv. Dent., 14, 2, 2011, p. 191

39.LOGUERCIO. A.D., REIS, A., SCHROEDER, M., BALDUCCI, I., VERSLUIS, A., BALLESTER, R.Y., J. Dent., 32, 2004, p. 459.

40.KINOMOTO, Y., TORII, M., J. Dent., 26, 1998, p. 16

41.WALTER, R., SWIFT, J.R.E, SHEIKH, H., FERRACANE, J.L., Quintessence Int., 40, 2009, p. 843.

Manuscript received: 8.01 .2018 